\title{
The Influence of Climate Factors on the Stability of Infrastructures: Case of Forest Ecosystem in Southern Cameroon
}

\author{
Philemon Zo'o Zame, Philippe Samba Assomo* \\ University of Yaounde I, Yaoundé, Cameroon \\ Email: "sambafilipe@yahoo.fr
}

Received 30 October 2015; accepted 26 December 2015; published 29 December 2015

Copyright (C) 2015 by authors and Scientific Research Publishing Inc.

This work is licensed under the Creative Commons Attribution International License (CC BY).

http://creativecommons.org/licenses/by/4.0/

(c) (i) Open Access

\begin{abstract}
The southern forest ecosystem of Cameroon extends from latitude $2^{\circ}$ to $6^{\circ} \mathrm{N}$ and from $10^{\circ}$ to $16^{\circ} \mathrm{E}$. In order to investigate about the influence of climate factors on the infrastructures, the main parameters of local climate of that ecosystem have been evaluated. The results show that, the factors are stable and have a common trend. But, the abundance of precipitations; the important hydrographic network and the presence of dense forest appear as the majors climatic constraints that may be taken in account to ensure the stability of the infrastructures in forest ecosystem.
\end{abstract}

Keywords

Forest Ecosystem, Climate Factors, Stability, Infrastructures, Cameroon

\section{Introduction}

The construction of various infrastructures (roads, buildings, bridges...) are based on technical specifications notably geotechnical parameters and the traffic in road domain. In order to know the cause of the rapid destruction of these infrastructures, it appears necessary to inquiry about the role played by the climate factors on the stability of the infrastructures. The purpose of this paper is to identify the impact of climate factors, on the stability of infrastructures independently, for the good consideration of technical guidance. The forest ecosystem in southern Cameroon is taken as an experimentation site.

\section{Situation and Presentation of the Field Studied}

The field studied extends from latitude $2^{\circ}$ to $6^{\circ} \mathrm{N}$ and from $10^{\circ}$ to $16^{\circ} \mathrm{E}$ (Figure 1). This area is covered by the

"Corresponding author.

How to cite this paper: Zo'o Zame, P. and Samba Assomo, P. (2015) The Influence of Climate Factors on the Stability of Infrastructures: Case of Forest Ecosystem in Southern Cameroon. International Journal of Geosciences, 6, 1317-1322.

http://dx.doi.org/10.4236/ijg.2015.612104 


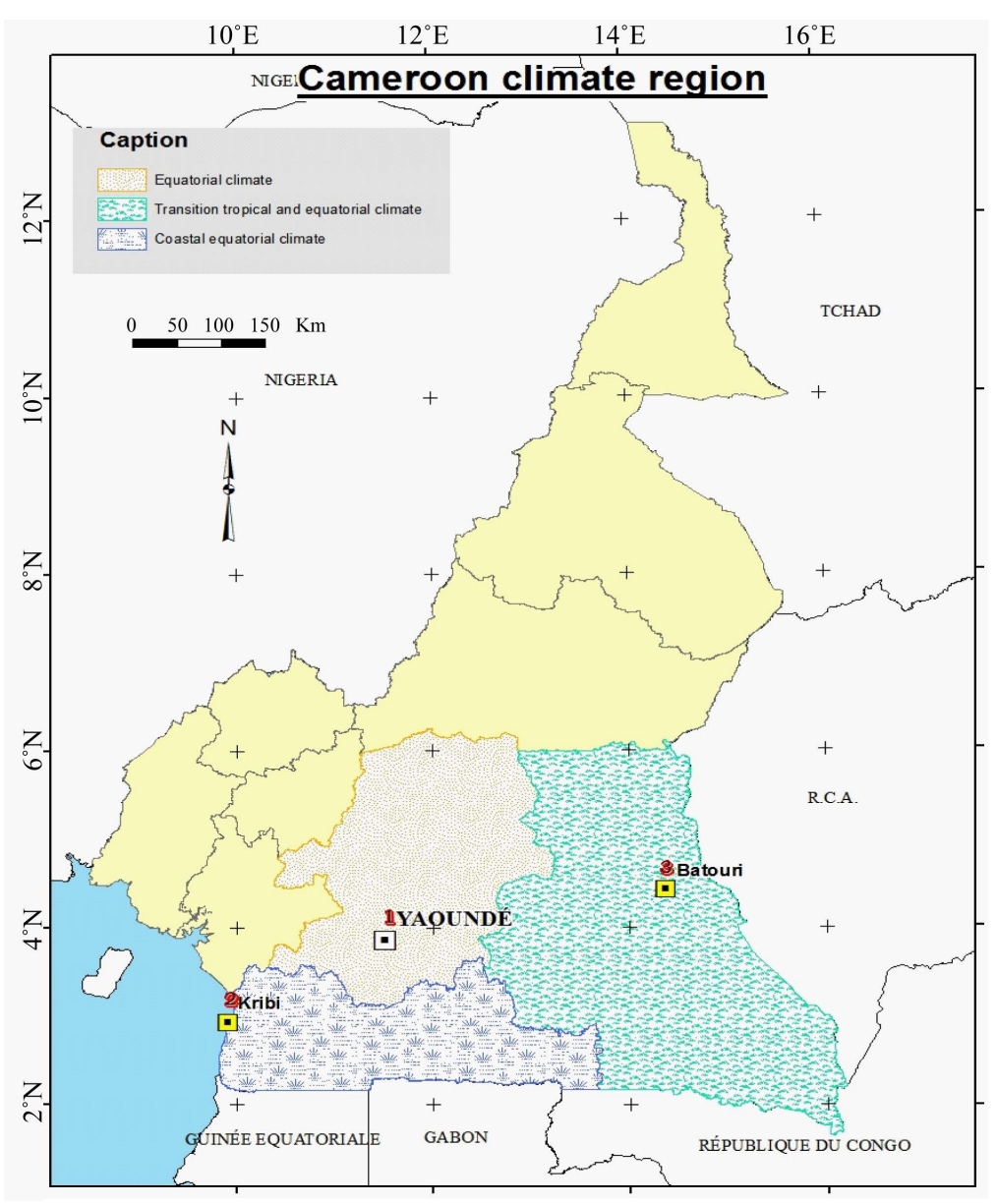

Figure 1. Location of studied field.

forest ecosystem and includes three regions: East (Bertoua), Center (Yaoundé) and South (Kribi). The coordinates of the localities in with different data have been collected are as follow: Yaoundé: LatLng (3.86136, 11.52077); Kribi: LatLng (2.93721, 9.91705) and Batouri: (4.43302, 14.36359). The works of Olivry, 1986 [1] cited by Kamgang Kabeyene, 1987 [2] and Bineli, 2009 [3] show that the area is the domain of equatorial climate that can be divided in three subtypes. In Yaoundé there is an equatorial climate with four seasons; in Kribi, the coastal equatorial climate with four seasons and increased humidity; in Batouri, transition tropical and equatorial climate.

According to many environmental assessments, the forest ecosystem has an important fauna and flora. The climate is characterized by:

- presence of dense forest with big and tall trees;

- abundance of precipitation;

- important and constancy temperature around $25^{\circ} \mathrm{C}$;

- important soil coat come from the weathering of original rocks.

\section{Methodology}

The methodology of this work is based on the exploitation of many reports of environmental assessment notably the studies of social and economic impact in the construction of the infrastructures that the Ministry of Publics Works is the promoter: "le Competing”, 2011 [4]; FHEC, 2013 [5]. The use of schematic maps was important to know about pedology and vegetation covers. To determine the climate factors as temperature and average of precipitation, the data was collected into the raining stations of the three localities chosen. The drawing up of specific diagrams permits to identify the four seasons of equatorial climate. The National Laboratory of Civil 
Engineering of Cameroon and the laboratory of geotechnic of the University of Yaoundé I allow us to obtain geotechnical parameters of several authors: Ekodeck, 1984 [6]; Bitom, 1998 [7]; Samba, 2008 [8]; Onana, 2010 [9]; Zo’o Zame, 2012 [10]; Ntouala, 2013 [11].

\section{Presentation and Interpretation of Results}

\subsection{Presentation of Results}

\subsubsection{Climate Factors}

The components determined concerning the average temperature, the annual average precipitation, hydrographic network, vegetation, soil and the seasons (Table 1).

From the data of raining station of Yaoundé (Table 2), the Bagnouls and Gaussen, 1996 [12] diagram was built (Figure 2). This diagram shows in general the period of the different seasons in the forest ecosystem.

Table 1. Development of different climate factors in three sites of the ecosystem.

\begin{tabular}{|c|c|c|c|c|c|c|}
\hline & Precipitation & Temperature & Hydrography & Vegetation & Soil & Season \\
\hline Batouri & $\begin{array}{c}1200 \text { to } \\
1600 \mathrm{~mm} / \mathrm{an}\end{array}$ & $24^{\circ} \mathrm{C}$ & Important network & $\begin{array}{l}\text { Savanna } \\
\text { and forest }\end{array}$ & Ferralitic & 04 seasons \\
\hline Yaoundé & $\begin{array}{c}1200 \text { to } \\
2000 \mathrm{~mm} / \mathrm{an}\end{array}$ & $24^{\circ} \mathrm{C}$ & Important network & forest & Ferralitic & 04 seasons \\
\hline Kribi & $\begin{array}{c}2500 \text { to } \\
4000 \mathrm{~mm} / \mathrm{an}\end{array}$ & $22^{\circ} \mathrm{C}-29^{\circ} \mathrm{C}$ & Important network & forest & Ferralitic & 04 seasons \\
\hline
\end{tabular}

Table 2. Raining parameters in the station of Yaounde from 1994 to 2014.

\begin{tabular}{ccccccccccccccccccc}
\hline Months & Jan & Feb & Mar & Apr & May & Jun & Jul & Aug & Sept & Oct & Nov & Dec & Total \\
\hline Precipitation $(\mathrm{mm})$ & 24.3 & 49.0 & 98.4 & 157.0 & 82.1 & 129.9 & 51.9 & 78.1 & 224.9 & 259 & 103.1 & 31.2 & 1288.9 \\
Temperature $\left({ }^{\circ} \mathrm{C}\right)$ & 24.2 & 25.4 & 25.2 & 24.8 & 24.6 & 23.9 & 23.2 & 23.3 & 23.7 & 23.7 & 23.4 & 24.4 & 24.15 \\
\hline
\end{tabular}

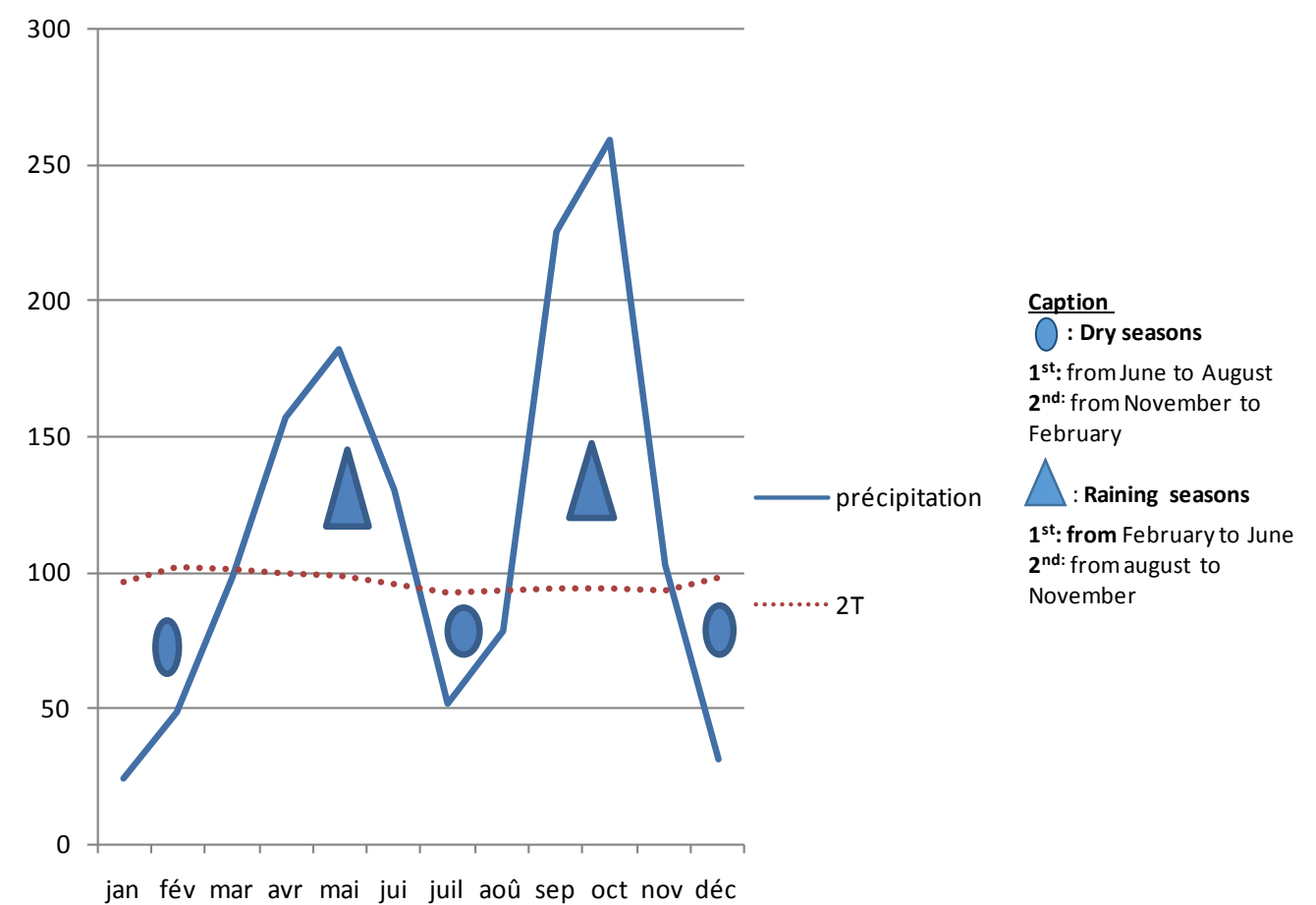

Figure 2. Ombrothermic diagram of Bagnouls and Gaussen applied to Yaoundé region. 
Another important component of climate is the soil. The ferralitic soil of forest ecosystem in equatorial climate has been described by Yongue, 1994 [13] Bekoa, 1994 [14] and 1998, [7]. According to the above authors, the ferralitic soil is acidic. It contains an important pedological cover due to weathering of original rocks of geological substratum. This profile shows three levels upwards (Figure 3):

- The inferior level that is characterized by the beginning of the fragmentation of original rocks. This fragments are called "altérites";

- The median level that contains various elements with different size come from broken rocks;

- The superior level rich in clay and organic matter.

Also, it is necessary to note that, apart from the general organization of the ferralitic soil, near the sea or important river the soil becomes hydromorphic rich in alluvium with poor mechanic properties.

According to the important hydrographic network announced above, the case of one locality of Yaoundé (Akonolinga) is follow represented (Figure 4).

\subsubsection{Geotechnical Parameters}

The geotechnical parameters of the sites are constant due to the common organization of the soil through the forest ecosystem. The parameters that have been chosen are volumic weight $(\gamma)$, porosity (n), Californian Bearing Ratio (CBR), apparent cohesion (Cu) and internal friction angle ( $\varphi$ u). The Table 3 gives the average of these parameters.

\subsection{Interpretation of Results}

The results obtained are stable not only in climate factors but also in geotechnical parameters. In the first approach, these results may allow the sustainability of infrastructures in southern forest ecosystem in case of civism of population and suitable technical management of works. But it is important to underscore the negative effect that play the combination of three climate factors on the stability of infrastructures in southern ecosystem notably the abundance of precipitation, the important hydrographic network and the dense forest.

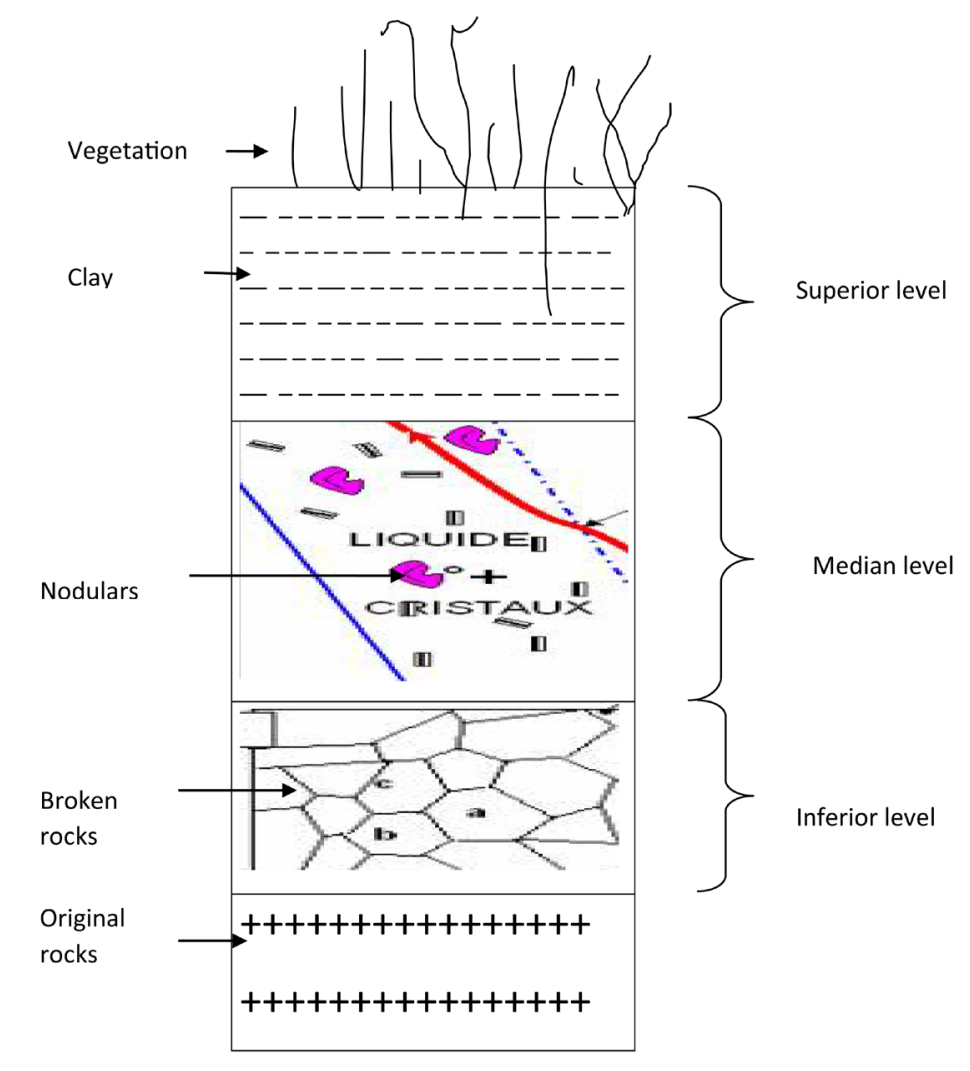

Figure 3. Pedological profile of ferralitic soil. 


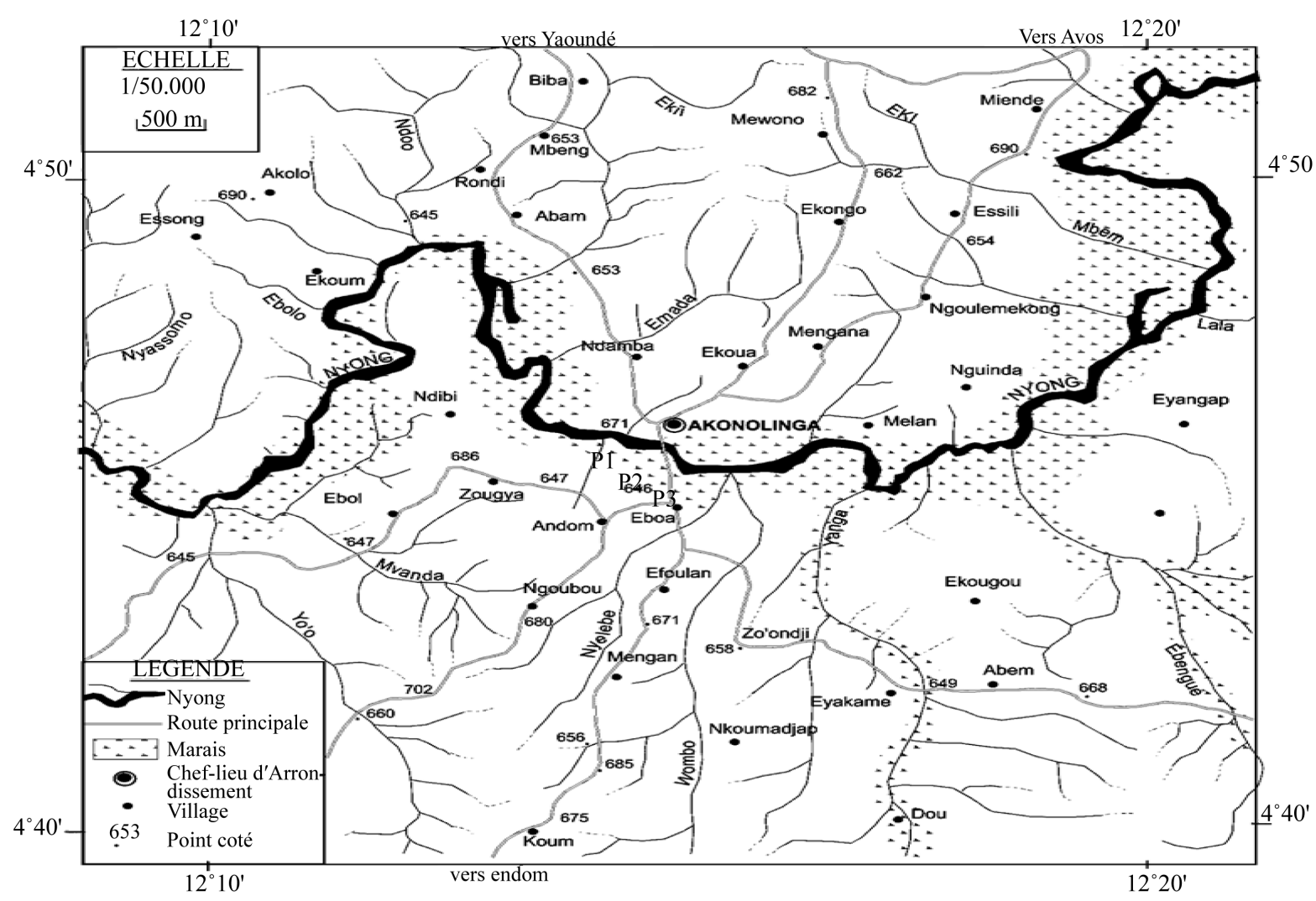

Figure 4. Hydrographic network in one locality of Yaoundé: Akonolinga.

Table 3. Geotechnical parameters.

\begin{tabular}{lccccc}
\hline & $\gamma\left(\mathrm{gf} / \mathrm{cm}^{3}\right)$ & $\mathrm{N}(\%)$ & $\mathrm{CBR}(\%)$ & $\mathrm{Cu}(\mathrm{bars})$ & $\Phi\left({ }^{\circ}\right)$ \\
\hline Superior level & 2.6 & 55 & 13 & $0.00-1.06$ & $12-52$ \\
Median level & 2.8 & 39 & 59 & $0.15-1.00$ & $31-63$ \\
Inferior level & 2.6 & 23 & 27 & $0.06-2.8$ & $16-50$ \\
\hline
\end{tabular}

a) the abundance of precipitation and the important hydrographic network facilitate the infiltration of water in infrastructures bodies that creates the loss of resistance; the water overflowing which causes erosion and the obstruction of canalization;

b) the permanent presence of forest is responsible of the fragmentation of the infrastructures by the phenomena induce by roots growing.

\section{Discussion}

The interaction between climate and infrastructures was the great preoccupation of many researches in this last decade. But, among these studies, many of them were related to the climate change and had global signification. The report of USAID, 2014 [15] presented the impacts of climate stressors on building due to climate change; this study also underlined the place of climate variability because any building is typically designed for specific climate. Several others reports show that climate change alter current conditions as temperature, precipitation, sea level or bed river and standard events. The consequence is the damage of various infrastructures: transportation infrastructures, buildings, marine infrastructures, energy infrastructures and roads: IISD, 2013 [16]; NCA, 2012 [17]. The case study of Southern Australia related to the impact of heat waves on infrastructures and communities conducted by the Queensland university of technology, 2010 [18] is in agreement with others works. The local impact of climate factors on the stability of infrastructures was introduced by Sarrazin et al., 
2009 [19]. The results obtained in forest ecosystem in southern Cameroon have the common trend of those showed elsewhere. The peculiarity in southern Cameroon is that the climate factors are local, the study is punctual and the ecological parameters are integrated.

\section{Conclusion}

The climate factors that induce negative effect on the stability of infrastructures in southern forest ecosystem of Cameroon are now known. There are the abundance of precipitation, an important hydrographic network and the existence of dense forest that cause the damage and the dysfunctioning of infrastructures. These negative impacts appeal to the strengthening of roadway or foundations and the reinforcement of canalization works. All over the world, the several others factors act negatively on the stability of infrastructures. So that, the attention of the authorities and any expert involved in the construction of infrastructures is called in order to take in account the different impacts linked to the climate factors in additional to the technical specification.

\section{References}

[1] Olivry, J. (1986) Fleuves et Rivières du Cameroun. Collection Monographies Hydrologiques ORSTOM nº9, Paris, I Vol. $733 \mathrm{p}$.

[2] Kamgang Beyala, V. (1987) Altération supergène des roches grenatifères de la région de Yaoundé (Cameroun): Pétrologie-Minéralogie. Th. Doct. 3ème Cycle, Université de Poitiers, Poitiers, 170 p.

[3] Bineli, E. (2009) Impact de la variabilité climatique sur les ressources en eau du bassin du Nyong. Mém. DEA. FAC. Sc. UYI., 82 p.

[4] Le Competing, B.E.T. (2012) Adaptation des infrastructures routières aux écosystèmes locaux. Rapport définitif, Ministère des Travaux Publics. Yaoundé, 150 p.

[5] FHEC (2013) Etude d'Impact Environnemental et Social du projet de construction de l'autoroute Yaoundé-Douala. Rapport provisoire, Ministère des Travaux Publics. Yaoundé, 268 p.

[6] Ekodeck, G. (1984) Altération des roches métamorphiques du Sud Cameroun et ses aspects géotechniques. Th. Doct. Univ. Scientif. Et Médic., Grenoble I, 368 p.

[7] Bitom, D. (1998) Organisation et évolution d'une couverture ferralitique en zone tropicale humide (Cameroun). Genèse et transformation d'ensemble ferrugineux induré profond. Thèse, Université de Poitiers, Poitiers,164 p.

[8] Samba Assomo, P. (2008) Caractérisation géotechnique des argiles alluvionnaires de la vallée du Nyong dans la région d'Akonolinga. Amorce de l'étude du mélange argile + ciment. Mém. DEA. Faculté des Sciences Université de Yaoundé I, Yaoundé, 64 p.

[9] Onana, V. (2010) Altération supergène des chloritoschistes de la série de Mbalmayo-Bengbis (Sud Cameroun) et ses implications géotechniques. Th. Doct. /Ph.D, Faculté des Sciences Université de Yaoundé I, Yaoundé, 242 p.

[10] Zo’o Zame, P. (2012) Caractérisation pétrographique des roches carbonatées de Mintom en vue d'une utilisation industrielle locale Th. Doct. Ph.D, Université de Yaoundé I, Yaoundé, 135 p.

[11] Ntouala, F. (2013) Altération supergène des chloritoschistes d'Ayos (Centre Cameroun) Th. Doct./Ph.D, Faculté des Sciences Université de Yaoundé I, Yaoundé, 2 p.

[12] Bagnouls, F. and Gaussen, H. (1996) Climats et leurclassification. Annales de Géographie, XXVI, 193-220.

[13] Yongue, R. (1995) Concentrations métallifères de nickel et de cobalt à partir de l'altération latéritique des roches ultrabasiques serpentinisées du Sud-Est du Cameroun. Th. Doct. Etat, Université de Yaoundé I, Yaoundé, 262 p.

[14] Bekoa, E. (1994) Etude pétrologique et géochimique d’une couverture pédologique sur gneiss en zone forestière de l'extrême Sud Cameroun : relation avec la dynamique du fer. Thèse. Doc $3^{\text {eme }}$ cycle, Université de Yaoundé I, Yaoundé, $187 \mathrm{p}$.

[15] USAID (2012) Addressing Climate Change Impact on Infrastructures: Preparing for Change. Building, 4 p.

[16] Boyle, J., Cunningham, M. and Dekens, J. (2013) Climate Change Adaptation and Canadian Infrastructures. Report for International Institute for Sustainable Development (IISD), $40 \mathrm{p}$.

[17] NCA (2012) Climate Change and Infrastructures, Urban System and Vulnerabilities. Technical Report to the US Department of Energy in Support of the National Climate Assessment, 119 p.

[18] Queensland University of Technology (2010) Impacts and Adaptation Responses of Infrastructures and Communities to Heatwaves: The Southern Australian Experience. The Report for the National Climate Change Adaptation Research Facility (NCCARF), $163 \mathrm{p}$.

[19] Sarrazin, D., Allard, M. and Leclerc, A. (2009) Climate Interaction on Infrastructures in Thediscontinuous Permanent zone, University of Laval, Quebec City, 25 p. 